\title{
Küreselleşmenin Türkiye'de Sivil Toplum-Dış Politika İlişkisine Yansımaları
}

\author{
DOI: $10.26466 /$ opus.693171
}

*

\author{
Nurbanu Bulgur * \\ * Doktor Adayı, Sakarya Üniversitesi \\ E-Posta: nurbanubulgur@gmail.com \\ ORCID: $\underline{0000-0001-7365-2518}$ \\ Öz
}

Küreselleşmenin bir sonucu olarak uluslararası ilişkilerde devlet ve sivil toplum ilişkisinin dönüşmesi, geleneksel diplomasinin yanında bir yumuşak güç örneği olarak kamu diplomasisini ortaya çıkarmıştır. Devletler tarafindan yürütülen kamu diplomasisi faaliyetleri, zamanla sivil toplum kuruluşlarının da etkin rol aldı̆̆ı bir alan haline gelmiştir. Ulusal ve uluslararası düzeyde meydana gelen bu gelişmelerden Türkiye de etkilenmiş ve sivil toplum kuruluşlarının uluslararasılaşması bu noktada başlamıştır. Özellikle 80'li yıllardan itibaren Türkiye'de neo-liberalizm odaklı dış politika söylemlerin yoğun olarak kullanılmasıyla sivil toplum kuruluşları daha fazla önem kazanmıştır. Insani yardım faaliyetleri, ekonomik ilişkilerin geliştirilmesi başlıkları sivil toplumu ön plana çıkaran söylemler ve uygulamalarm bel kemiğini oluşturmuştur.

Ancak toplumsal, siyasal ve ekonomik anlamda bazı farklklardan dolayı, Türkiye'de STK'lar gelişmiş toplumlardaki etkinlik düzeyine sahip değildir. Neticede Türkiye'deki STK'lar küreselleşme gibi gelişmelerden etkilenmiş, uluslararasılaşmış fakat dış politika inşasına, işleyişine müdahale edebilecek kapasiteye ulaşamamıştır. Fakat Türkiye'nin dış politikasının uygulanmasında, farklı bölgelere tanıtılmasında ve özellikle yardım faaliyetlerinde etkin rol almaktadırlar.

Anahtar Kelimeler: $\quad$ STK, Türkiye, Küreselleşme, Dış politika, Uluslararasılaşma 


\title{
The Reflections of Globalization Towards The Relation Between Civil Society and Foreign Policy in Turkey
}

\begin{abstract}
As a result of globalization, the transformation of the state and civil society relationship in international relations has revealed public diplomacy as an example of soft power as well as traditional diplomacy. Public diplomacy activities carried out by states have become an area in which non-governmental organizations play an active role in time. Turkey was also affected from these developments occurring at national and international level in the world. The internationalization of civil society organizations have started at this point. Especially since the 80's of neo-liberalism driven by the intensive use of the discourse civil society organizations in Turkey has become more important. Humanitarian aid activities and the development of economic relations have formed the backbone of the discourses and practices that bring civil society to the fore.

However, because of the social, political and economic sense due to some differences, NGOs in Turkey does not have the level of activity like the developed societies. NGOs in Turkey ultimately influenced by developments such as globalization, internationalization has been built, but, has not reached the capacity to interfere with foreign policy discourse and construction. But NGO's are taking an active role particularly in the humanitarian activities and the implementation and promotion of Turkey's foreign policy in the different regions.
\end{abstract}

Keywords: NGOs, Turkey, Globalization, Foreign Policy, Internationalization 


\section{Giriş}

Uluslararası sistem", uluslararası aktörlerin küresel arenada sürdürdüğü bir etkileşim modeli olarak tanımlanmaktadır (Kegley ve. Wittkopf, 2004, s.8-10). Uluslararası İlişkiler genel manada devletin temel aktör olduğu devletlerarası ilişkilerin yürütüldüğü bir alan olarak görülmektedir (Willetts, 2001, s.357). Özellikle uluslararası ilişkilerde "aktör" kavramı üzerine yapılan tanımlar da devleti işaret etmektedir. Bunlara birkaç örnek vermek gerekirse; "James Dougherty'ye göre uluslararası aktör, “...uluslararası arenada az veya çok bağımsız eylemler geliştirme yeteneğine sahip organize bir varlık" iken; "Hopkins- Mansbach ikilisi aktörü "diğer otonom aktörlerin davranışları üzerinde etki uygulayan, nispi olarak otonom bir birim" olarak ifade etmektedir (Dougherty ve Pfaltzgraff, 1990, s.18; Sönmezoğlu, 2005, s.20).

"Uluslararası ilişkiler" ifadesindeki "uluslar" kavramı ise sadece devletler olarak ele alındığından, devlet temel aktör olarak görülmüştür (Arı, 2010, s.13).

Ancak devletlerin ana aktör olarak kabul gördüğ̈̈ yapı, hızlı bir dönüşüm geçirerek, devletdışı aktörlerin de aktif bir şekilde rol aldığı yeni bir yapıya yerini bırakmıştır (Miall, 1999:35). Çatışma çözümü gibi konularda ulusal ve uluslararası (Birleşmiş Milletler (BM)) sivil toplum kuruluşlarının ve hükümetdışı kuruluşların yer alması bu değişen duruma bir örnektir. Dolayısıyla devletdışı aktörlerin bu alandaki faaliyetleri gelişmiş ve etki alanları genişlemiştir (Yalçınkaya, 2006, s.505).

Bütün bu gelişmeler ışığında; bu çalışma içerisinde küresel ölçekte yansımaları olan uluslararasılaşma sürecinin Türkiye'de dış politika ve sivil toplum ilişkisine etkisinin incelenmesi amaçlanmaktadır.

\section{Yöntem}

Bu çalışmada nitel araştırma yöntemi tercih edilmiştir. Nitel bir araştırma sürecinde araştırma planının oluşturulmasına dair farklı yöntem ve perspektifler mevcuttur. Örneğin; Joseph A. Maxwell'in çalışma önerisi için belirlediği dokuz parametresi, John Creswell'in araştırma deseni ve planı üzerine geliştirdiği yöntem ve aşamalar, Morse ve Richard'ın metodolojik uyum kavramı, araştırma yöntemleri literatürüne yapılan önemli katkılardandır (Morse ve Richards, 2002, s.15; Creswell, 2017, s.180-186). 
Bu çalışmada esas alınacak olan metodolojik uyum kavramını detaylandırmak gerekirse; "çalışmanın bölünmüş, izole parçalarından ziyade tutarlı bir bütün olarak görünmesi için araştırma amaçları, soruları ve yöntemlerinim tümüyle birbiriyle bağlantılı ve ilişkili olması" anlamına gelmektedir (Morse ve Richards, 2002, s.15; Creswell, 2017, s.13-15). Bu süreçte araştırmacı bu birbiriyle bağlantılı parçaları takip etme eğilimindedir.

Yöntem, amaç ve araştırma sorularının bütünlüğünü önemseyen araştırmacilardan birisi de John Creswell'dir. Creswell, “Research Design: Qualitative Quantitative And Mixed Methods Approaches" adlı kitabında nitel araştırmanın temel karakteristik özellikleri şöyle sıralamıştır: Doğal ortam, temel araç olarak araştırmacl, çoklu yöntemler, tümevarım ve tümdengelimli mantık yoluyla karmaşık akıl yürütme, zamanla beliren desen, yansıtıcılık, bütüncül açıklama (Creswell, 2017, s.185-187).

Çalışmada nitel araştırma yönteminin temel özellikleri ve akademik etik kuralları dikkate alınarak bir araştırma planı oluşturulup konunun analiz edilmesi amaçlanmaktadır. Bu doğrultuda nitel araştırma yöntemlerinden olan kaynak incelemesi, teorik araştırma ve olay incelemesi kapsamında üniversite, kütüphaneler, çevrimiçi veri tabanları kullanılarak, Türkçe ve yabancı kaynaklardan (bilimsel raporlar, akademik makale, kitap, bildiri vb.) yararlanilacaktır.

\section{Türkiye'de Sivil Toplum Kuruluşlarının Gelişimi}

20. yüzyılın ortalarından itibaren uluslararası ilişkilerde ve dış politikada yaşanan değişim sivil toplumun etkisini arttırmış ve sivil toplum diş politika ilişkisine yeni bir boyut kazandırmıştır. Soğuk Savaşın bitmesi, sivil toplum olgusuna yönelik olumsuz algının zamanla kaybolmasını sağlamıştır. Aynı dönemde bilgi ve iletişim teknolojilerinde yaşanan hızlı gelişme, ülke dışındaki siyasi ve toplumsal oluşumlardan ve değişimlerden kısa sürede haberdar olmamızı sağlamıştır.

Bunun yanı sıra internet daha etkili bir siyasal araç haline gelmiştir (Ateş ve Uysal, 2006, s.69). Arap Baharı sürecinde sosyal medyanın ve iletişim teknolojilerinin rolü, teknolojinin sivil toplumun gelişimine yaptı̆̆ etkiye örnektir.

Tarihsel çerçevede vakıf gibi bir geçmişe sahip olmasına rağmen, Türkiye'de ise bugünkü anlamda sivil toplum olgusu yeni ve az gelişmiştir 
(Mağa, 2001, s.7-17). Türkiye'de kamunun aktif katılımıyla faaliyet gerçekleştirme hususunda sorunlar mevcuttur. Nitekim sivil toplum kuruluşlarında örgütlülük, iradi beraberlik, demokratik iç yapıya sahip olma ve kamunun aktif katılımı esastır.

Bu çerçevede eğitim ve sağlığın da dahil olduğu pek çok alanda, devlet üstlendiği görevleri STK'lara ya da özel sektöre bırakmaktadır ("Avrupa Birliği”, 2001). Türkiye'de sivil toplumu temsil edebilecek olan birçok STK faaliyet göstermektedir. STK'ları aşağıdaki gibi gruplandırmamız mümkündür ( Çaha, 2017, s.75-80).

1. "Mesleki" sivil toplum örgütleri (Meslek Odaları, birlikleri ve medya kuruluşları),

2. İşveren kuruluşları/profesyonel federasyonlar: 1980 öncesinde faaliyet gösteren TİSK ve TÜSİAD (TÜSİAD, 2017) gibi işveren örgütleri ve 1980 sonrasında MÜSİAD (MÜSİAD, 2017), AGİAD, ASKON, GESİD, TÜGİAD, KAGIDER gibi işveren dernekleri,

3. İşçi ve memur sendikaları: TÜRK-İŞ, HAK-İŞ, DİSK, Memur-Sen, KamuSen ve KESK,

4. "Hak ve özgürlükler" alanında gelişen sivil toplum örgütleri: İnsan Hakları Derneği, Mazlum- Der,

5. Geleneksel muhafazakâr sivil toplum örgütleri: Maarif Vakfı

6. Düşünce Platformu alanında gelişen sivil toplum örgütleri: Liberal Düşünce Topluluğu, Özgürlük Araştırmaları Derneği, TESEV, TÜSEV,

7. Etnik ve kültürel haklar etrafında ortaya çıkan sivil toplum örgütleri: Kafkas dernekleri, alevi dernekleri, Kürt hareketi,

8. Sivil toplum cephesi olarak dikkat çeken alanlardan biri de çevre konusundaki duyarlılık ve hassasiyetlerde görülmektedir: TEMA, Türkiye Çevre Vakfı, Doğal Hayatı Koruma Derneği,

9. Diğer bir kategori de 1980'li yıllarda gelişen Atatürkçü Düşünce Derneği ve Çağdaş Yaşamı Destekleme Derneği gibi Atatürkçü çizgideki örgütleri içermektedir (Çaha, 2017, s.75-80).

10. Sivil toplum örgütlerinin geliştiği diğer bir alan da arama-kurtarma ve yardımlaşma faaliyetleridir: AKUT, Deniz Feneri, Türk Kızılayı, Diyanet Vakfı, İnsan Hak ve Hürriyetleri İnsani Yardım Vakfı (ïHH), Gönüllüler, Hayrat İnsani Yardım Vakfı, Aziz Hüdayi Vakfı, Cansuyu Yardımlaşma ve Dayanışma Derneği, Yardımeli Uluslararası İnsani Yardım Derneği, 
Yeryüzü Doktorları, Arama Kurtarma Derneği, Beşir Derneği, Sadakataşı Derneği, Vuslat Derneği

11. Ayrıca Türkiye'de faaliyet gösteren uluslararası NGO'ları da sivil toplum alanına dahil edebiliriz: Conrad Adenaur vakfı, Uluslararası Af Örgütü, Helsinki İzleme Komitesi, Green Peace vb.

Devletin toplum üzerindeki hakimiyetinin azalması ile sivil toplum kuruluşlarının oluşumu kolaylaşmış ve hareket alanı genişlemiştir.

İç ve dış politikadaki değişimler, küreselleşme, uluslararası alandaki değişimler, patlak veren uluslararası insani sorunlar ve ortaya çıkan uluslararası tehditler STK'lara düşen rolü arttırmıştır ${ }^{1}$. Küreselleşmenin birçok sorun ve konu üzerinde süregelen domino etkisi ile Türkiye de dünyadaki bu gelişmelerden etkilenmiştir.

Böylece sivil toplum kuruluşları diplomasinin temel aktörlerinden biri olmuş, devletlerin diş politika söylem ve uygulamalarında faal olmaya başlamışlardır. Bu gelişmeler neticesinde sivil toplum kuruluşlarının uluslararasılaşma süreci hızlanmış ve günümüzde devletin tek başına yürütmediği kamu diplomasisi faaliyetlerinde üstlendikleri rolü güçlendirmiştir.

Şule Kut bu durumu "hem uluslararası sorunlar hem de dış politika, Türkiye'de kamuoyu tarafından belki de hiç olmadığı kadar tartışılır olmuştur" şeklinde ifade ederken (Kut, 1998, s.13), Barry Rubin "Devletin büyük oranda otonom davranarak, belirli politika ve yapıları üstten empoze ettiği eski sistem", "çıkar grupları ve siyasi çoğulculuğun" geliştiği "dış politikayı şekillendiren ve etkileyen farklı güçlerin ortaya çıktığı" farklı bir dış politika ortamına dönüşmüştür" cümlesi ile sivil toplumun gelişimini özetlemiştir (Rubin, 2002, s.13).

Cicioğlu'na göre ise "sivil toplum, devlet ile ekonomi ve aile arasında kalan sivil toplumsal sorunları çözmeye dönük bir kamusal tartışma alanı ve bu tartışmanın yaşama geçirildiği örgütsel etkinliktir" (Cicioğlu, 2010, s.82-86).

Kültürel, ticari, eğitim faaliyetlerini de kapsayan kamu diplomasisi uygulamalarında özel sektör ve STK'lar devletler ve toplumlar arasındaki koordinasyonun sağlanmasında görev almıştır (Tuncer, 2009, s.128).

\footnotetext{
1 Uluslararası alandaki değişimler: Arap Baharı, Mavi Marmara olayı, Kıbrıs sorunu çözümü için ortaya atılan Annan Planı, Irak'ta yapılan referandum ve Türkiye'deki STK'ların tepkisi, patlak veren uluslararası insani sorunlar: Arakan'daki insani kriz, Afrika'daki yoksulluk, ortaya çıkan uluslararası tehditler: Daeş, EI Kaide vb. radikal örgütler.
} 
Yirminci yüzyılın başında gerçekleşen iki dünya savaşının devlet ve toplum üzerindeki yıkıcı etkileri geleneksel diplomasi faaliyetlerinin insani diplomasi yönüne evrilmesine sebep olmuştur. Bu noktada yapılanma şekli ve çalışma tarzından ötürü STK'lar toplumsal bağların güçlendirilmesi ve kamu diplomasisinin yürütülmesinde etkin rol almıştır.

Türkiye'de ise STK'lar, uluslararasılaşma sürecinde kültürel ilişkilerin geliştirilmesi, kültürel değerlerin ve eserlerin korunması ve tanıtılması alanında görev almıştır. Vakıf hareketleri, tarihi yapıların korunması, eğitim faaliyetleri (Türkçe eğitimin yaygınlaştırılması) kültürel faaliyetlere birer örnektir (Aydemir, 2016, s.355-356).

Sivil toplum kuruluşlarının etkinliğini arttırmasında önemli bir etkiye sahip olan dönüm noktaları vardır. Bu dönüm noktalarından biri BM'nin 1996 yılında gerçekleştirdiği HABITAT II konferansıdır. Bu konferansın ana odak noktasını oluşturan sürdürülebilir insan yerleşimleri, sürdürülebilir kentleşme politikaları sivil toplum kuruluşlarının aktif bir şekilde görev almasını sağlamıştır. ("Planning Sustainable Cities Un-Habitat Practices And Perspectives", 2010, s.3-6).

HABITAT II Konferansı neticesinde kabul edilen "İstanbul Deklarasyonu" ile herkes için gerekli konut ihtiyacının karşılanması konusunda toplantıların yapılması ve müzakerelerin sürdürülmesi hususunda sivil toplum kurluşlarına bir rol verilmiştir.(Türkiye Ulusal Rapor Taslağı, 1996, s.57).

Ancak STK'lar Türkiye'de, ülkenin çok boyutlu çkarlarını dikkate alarak hükümet tarafından belirlenen program dahilinde ve faaliyet yapılması hedeflenen bölge ve ülkelerde kamu kuruluşları ile koordine biçimde hareket etmektedirler.

Ülkemizde STK'ların faaliyet alanları ise şöyledir;

- İnsani yardım faaliyetleri

- Kültürel ilişkilerin geliştirilmesi

- Araştırma faaliyetleri

- Eğitim faaliyetleri

Bu faaliyetle alanları arasında, STK'ların en yoğun çalıştığı ve başarılı olduğu alanın ise insani yardım faaliyetleri olduğu tespit edilmiştir (BBC, 2013).

21. yüzyllda ise daha örgütlü ve daha aktif hale gelen sivil toplum kuruluşları, Türk dış politikasını yönlendirmekten ziyade ancak dış politikanın 
oluşumunda karar alıcılara bir fizibilite çalışması sunabilmiş ve diş politikanın uygulanmasında yardımcı role sahip olmuşlardır. Bunda Türkiye'de süregelen hakim devlet söyleminin etkisi büyüktür.

\section{Bulgular}

Sivil toplum kuruluşlarının üyeleri ancak, devletin herhangi bir biriminde yer alıp o kurumsal yapı içinde etkin olabilmektedirler. Bu da onların siyasileşmesine, yani sivil toplum kuruluşunun bir üyesi olma statüsünü yitirmelerine neden olmaktadır. Bu süreçte dış politika karar alıcıları; devletin kontrol ettiği ve ulusal ve uluslararası kamuoyu önünde kendini meşrulaştırdığ STK'ların bazılarını teşvik edebilmekte ve dış politika ilkeleri doğrultusunda onlara daha çok faaliyet alanı sunabilmektedir.

Fakat kendi normlarına, kurumlarına, kanunlarına ve hükmetme gücüne sahip olan devletin sivil toplum tipi bir örgütsel yönetime sahip olması ve ülkenin belli bir kesiminin ihtiyaç ve taleplerini karşılaması, ülke içinde kutuplaşmayı getireceğinden, söz konusu olamamaktadır.

Buradaki can alıcı nokta ve STK'lar için caydırıcı olan asıl konu devletin hükmetme gücü ve yetisidir. Devlet; yönetime ve dış politika uygulamalarına tehdit olarak algıladığında ya da gerekli gördügünde bazı STK'ları kapatabilir veya mali imkânlarını kısıtlayabilir. Ama STK'lar devletin işleyişine yön veremediği gibi devletin kurumlarını, kuruluşlarını ve kanunlarını etkileyememektedir. Bu bilgiler ışığında Türkiye'deki STK'ların zayıf ve diş politikayı yönlendirici etkiye sahip olamamasının temel sebeplerini şöyle sıralayabiliriz (Çaha, 2017, s.75-80);

1. Devlet korkusu: Devletten korku ve bunun getirdiği uyumluluk sivil toplumun çeşitliliğini ve farklıklarını köreltmektedir. Eleştirel bakışı, ifade özgürlüğünü ve özgünlüğü ortadan kaldırıp sivil toplum kuruluşlarını tekdüzeliğe itmektedir.

2. Devleti yücelten söylem: Türk siyasal kültürünün en temel kavramı olan devletin, bu kültür içinde yüceltilerek bireylerin ve toplulukların üzerine çkması söz konusudur. Sivil toplum örgütleri devlete bağımlı bu kültüre mecbur birakılmaktadır.

3. Ekonomik bağımlılık: Mülkiyet ve üretimin büyük kısmının devletin tekelinde olmasından ötürü, toplumsal direncin devlete bağımlı kalması sivil toplumun gelişmesine engel teşkil etmektedir.s 


\section{Tartışma ve Sonuç}

Edinilen bilgiler ışığında Türkiye'de sivil toplumun uluslararasılaşma süreci dünyadaki gelişmelerle doğrudan ilintilidir. Ulaşım, iletişim ve bilgi teknolojilerindeki hızlı gelişimi, toplumsal farkındalığın yükselmesini sağlamış, bölgeler ve devletlerarasındaki iletişimi zorunlu kılmıştır.

Bu doğrultuda küreselleşme ve uluslararasılaşması süreci ile STK'lar dış politika faaliyetlerinde daha çok yer almaya başlamış ve zamanla kurumsallaşmıştır. Kurumsallaşma beraberinde profesyonelliği getirmiş ve nitelikli çalışanlar için verimli bir çalışma ortamı oluşmuştur. Uluslararası faaliyet gösterilmesi aynı zamanda STK'ların çok kültürlü bir yapıya dönüşmesini sağlamış ve çok dil bilen personele olan ihtiyacı artırmıştır.

İnsan hakları, çatışma çözümü, iklim değişikliği, terörle mücadele gibi küreselleşen konularda inisiyatif kullanarak, çözüm üreterek ya da kamuoyu oluşturarak faaliyet gösteren STK'lar, kurumsallaşmayla birlikte aktif olarak hareket etmeye başlamıştır.

Fakat Türkiye'de sivil toplum kuruluşları küreselleşme gibi birçok konjonktürel değişimden etkilenerek uluslararası bir boyut kazansa da, devletten özerk otonom yapıya ulaşamamakta ve çoğunlukla dış politikayı meşrulaştırıcı bir araç olarak karşımıza çıkmaktadır. Bütün bilgiler ışığında söylenebilir ki; sivil toplum-dış politika ilişkisini güçlendiren, geliştiren bir faktör olan "küreselleşmeyle" birlikte, Türkiye'de sivil toplum kuruluşları kamuoyu oluşturmada etkin bir aktör haline gelmiştir. Fakat STK'ların birçoğunun faaliyetleri karar alıcıların dış politika ilkelerinin ve uygulamalarının gölgesinde kalmaktadır. Bu konuda Türkiye' deki devleti yücelten siyasal kültürün varlığı, STK'ların ekonomik olarak devlete bağımlılığı gibi etkenlerin rolü büyüktür. 


\section{EXTENDED ABSTRACT}

\section{The Reflections of Globalization Towards The Relation Between Civil Society and Foreign Policy in Turkey}

Nurbanu Bulgur

Sakarya Üniversitesi

Turkey's civil society organizations together with the second half of the 1980s, were seen in the process of a new beginning. During this period, government officials visited the Central Asian countries along with businessmen who had an indirect play an important role in the rise of civil society organizations. In addition, parallel to the developments in the world, after the military coup of September 12, 1980, the debate on "is the individual for the state or the state for the individual" attracted the attention of every part of the society and started to expand the field of civil society.

In terms of increasing the effectiveness of civil society, there are certain milestones that play a major role. One of them is the HABITAT II conference held in Istanbul in 1996. UN-HABITAT was established to coordinate human settlements activities in the UN, to provide information on sustainable human settlements and resettlement programs, and to provide technical assistance and financial support to countries in solving the problems encountered in cities.

HABITAT II Conference, which results in the basic documents of the UNHABITAT "Habitat Agenda" and the "Istanbul Declaration" was adopted.

With these documents, governments have committed to providing all citizens with appropriate housing opportunities and developing sustainable human settlements. Main development which makes HABITAT II a landmark in terms of the development of civil society in Turkey is to negotiate the development of human settlements and sustainable urbanization.

After this conference, civil society began to gain the characteristic of being a community of organizations with individuals who are autonomous from the state and who are in a continuous development, who can direct and make sense of their own development without resorting to any upper identity. 1990s and later on in Turkey, as in many areas of civil society in the field has 
brought a number of opportunities and innovations. Another important reason for preparing the environment for these innovations was the end of the Cold War period.

The end of the Cold War paved the way for the gradual dissolution of the phenomenon of society and the solid formation on societies at a more concrete level. At the same time, the fact that the restrictions in the economic and technological fields started to decrease in the same period contributed to the formation of civil society and the spread of the concept of "awareness", which is an important element of civil society.

In the early 2000s, with the decrease of the state monopoly on the society, the pressure on civil society started to disappear and the organization of civil groups started to increase. Changes in domestic and foreign policy, globalization, changes in the international arena, international humanitarian problems, and emerging international threats have increased the role of NGOs. NGOs are unlikely to be affected by Turkey's development, while important in the world. Therefore, NGOs are gaining increasing importance in a way every day in Turkey.

With the change in traditional diplomacy, non-governmental organizations have become one of the main actors of diplomacy and have started to take part in the foreign policy planning and implementation processes of the states. Within the framework of these norms, one of the domains of non-governmental organizations is the public diplomacy activities in the foreign policy processes of states.

Governments today do not carry out public diplomacy alone. In addition to governments, non-governmental organizations, research centers, private sector and non-governmental organizations play important roles in the execution phase, while governments also coordinate the cooperation between organizations outside their own.

After the devastating consequences of the Second World War, the domain and target of diplomatic activities in foreign policy has taken into account individuals as well as states. As a result, the process of using non-governmental organizations in public diplomacy has started. Non-governmental organizations, which have an intense relationship with the public in terms of their structure and work, have an important effect on public diplomacy as they affect policy makers in the process of law making. However, they also act by 
considering the interests of their countries in the foreign policy execution process. At this point, Turkish non-governmental organizations generally implement them as determined by the government.

If we want to sort the tasks of NGOs in Turkey; Humanitarian Aid Activities, Foreign Economic Relations and Research, Education and Cultural Studies. In Turkish foreign policy and public diplomacy, humanitarian aid is one of the areas where non-governmental organizations work most intensively and are in the most successful position. These activities are carried out and managed in coordination by public institutions and non-governmental organizations in the target regions.

\section{Kaynakça / References}

Avrupa Birliği, (2001). Devlet ve STK'lar. Türkiye'de Sivil Toplum Kuruluşları Sempozyumu VII, İstanbul: Türkiye Ekonomik ve Toplumsal Tarih Vakfı Yayınları.

Aydemir, E. (2016). Dış politikada yumuşak güç ve medya. İstanbul: Kalkedon Yayınları. Birleşmiş Milletler İnsan Yerleşimleri Konferansı Habitat II. (1996). Türkiye Ulusal Rapor ve Eylem Plânı. İstanbul Haziran.

Cicioğlu, F. (2010). Ermenistan ve Kıbrıs sorunu bağlamında Türk dış politikası ve sivil toplum kuruluşları. Akademik Incelemeler Dergisi. 5(2).

Creswell, J. (2017). Araştırma deseni: Nitel, nicel ve karma yöntem yaklaşımları. (Selçuk B. Demir vd., Çev.). Ankara: Eğiten Kitap Yayıncılık.

Çaha, Ö. (2017). Sivil toplum sivil topluma karşı: Sivil toplumun Türkiye'deki ve dünyadaki serüveni. İstanbul: Mana Yayınları.

Dougherty, J. E., Robert, L. ve Pfaltzgraff, Jr., (1990). Contending theories of international relations: A comprehensive survey. 3rd ed. New York: Harper and Row Publishers.

İnsani Yardım Sıralamasında Türkiye Dördüncü (2013). BBC. 30 Mayıs 2017 tarihinde http://www.bbc.co.uk/turkce/haberler/2013/07/130717 turkiye insani yardim.shtml adresinden erişilmiştir.

Kegley, C. R. ve Eugene, R. W. (2004). World politics: Trend and transformation, (9th Ed). Canada: Thomson and Wadsworth.

Kut, Ş. (1998). Türkiye'nin soğuk savaş sonrası dış politikasının anahtarları. (G. Özcan ve Ş. Kut, Der.). En Uzun On Yıl: Türkiyénin Ulusal Güvenlik ve Dış Politika Gündeminde Doksanlı Yillar. İstanbul: Boyut Kitapları.

Mağa, İ. (2001). Sivil toplum devletin büyümesidir. İstanbul: YGS Yayınları.

Miall, H. and Tom Woodhouse. (1999). Contemporary conflict resolution: The prevention, management and transformation of deadly conflicts. USA: Polity Press. 
Morse, J. M. Ve Lyn, R.. (2002). Readme first for a user's guide to qualitative methods [13 paragraphs]. forum qualitative Sozialforschung. Forum: Qualitative Social Research, 5(1), 28.

MÜSİAD. (2017). Müsiad. 30 Mayıs 2017 tarihinde http://www.musiad.org.tr/tr-tr/subeler adresinden erişilmiştir.

Planning Sustainable Cities Un-Habitat Practices And Perspectives. (2010). United Nations Human Settlements Programme (Un-Habitat). https://www.researchgate.net/publication/283968045 Planning Sustainable Cities UN-HABITAT Practices and Perspectives adresinden erişilmiştir.

Rubin, B. (2002). Türkiye'nin dış politikasını anlamak. (B. Rubin ve K. Kiriş̧̧i, Der.). Günümüzde Türkiye'nin Dış Politikası. İstanbul: Boğaziçi Üniversitesi Yayınları.

Sönmezoğlu, F. (2005). Uluslararası politika ve dış politika analizi. İstanbul: Filiz Kitabevi.

Tuncer, H. (2009). Diplomasinin eorimi, gizli diplomasiden küresel diplomasiye. İstanbul: Kaynak Yayınları.

TÜSİAD. (2017). Tüsiad. 30 Mayıs 2017 tarihinde . http://www.tusiad.org/tr/tusiad/temsilcilikler adresinden erişilmiştir.

Willetts, P. (2001). Transnational actors and international organizations in global politics. (J. Baylis and S. Smith, Ed.). The Globalization of World Politics: An Introduction to International Relations. 2. Ed.. New York: Oxford University Press.

Yalçınkaya, H. vd. (2006). Değişen silahlı çatı̧ma ortamında sivil toplum kuruluşlarının güvenlik ihtiyaçlarının karşılanması: Afganistan ve Anso örneği. III. Uluslararası Sivil Toplum Kuruluşlanı Kongresi, Bildiriler Kitabı: STK-Özel SektörDevlet Etkileşimi. Çanakkale Onsekiz Mart Üniversitesi Biga İktisadi ve İdari Bilimler Fakültesi, Çanakkale.

\section{Kaynakça Bilgisi / Citation Information}

Bulgur, N. (2020). Küreselleşmenin Türkiye'de sivil toplum-dış politika ilişkisine yansımaları. OPUS-Uluslararası Toplum Araştırmaları Dergisi, 16(31), 4493-4505. DOI: 10.26466/opus.693171 